\title{
ATIQCTPC targeting MMP-9: a key step to slowing primary tumor growth and inhibiting metastasis of lewis lung carcinoma in vivo
}

\author{
Yuji Wang ${ }^{1}$, Xinyi Xu ${ }^{1}$, Ce Song ${ }^{3}$, Jianhui Wu ${ }^{1}, X_{i} H^{1}$, Haimei Zhu ${ }^{1}$, Xiaoyi Zhang ${ }^{1}$, \\ Yaonan Wang ${ }^{1}$, Lin Gui ${ }^{1}$, Ming Zhao ${ }^{1,2}$ and Shiqi Peng ${ }^{1}$ \\ ${ }^{1}$ Beijing Area Major Laboratory of Peptide and Small Molecular Drugs, Engineering Research Center of Endogenous Prophylactic \\ of Ministry of Education of China, Beijing Laboratory of Biomedical Materials, College of Pharmaceutical Sciences, Capital \\ Medical University, Beijing, China \\ ${ }^{2}$ Department of Biomedical Science and Environmental Biology, Kaohsiung Medical University, Kaohsiung, Taiwan \\ ${ }^{3}$ Ruikang Hospital, Guangxi University of Chinese Medicine, Nanning, China \\ Corrospondence to: Shiqi Peng, email: sqpeng@bjmu.edu.cn \\ Ming Zhao, email: mingzhao@bjmu.edu.cn \\ Ce Song, email: songce.ruikang@outlook.com \\ Keywords: MMP-9, tumor, metastasis, inflammation, TNF-a \\ Received: February 02, $2017 \quad$ Accepted: June 02, $2017 \quad$ Published: July 10, 2017 \\ Copyright: Wang et al. This is an open-access article distributed under the terms of the Creative Commons Attribution License 3.0 \\ (CC BY 3.0), which permits unrestricted use, distribution, and reproduction in any medium, provided the original author and source \\ are credited.
}

\section{ABSTRACT}

In this study we docked (6S)-3-acetyl-4-oxo- $\mathrm{N}-(2-(3,4,5,6-z e t r a h y d r o x y t e t r a h y d r o-$ 2H-pyran-2-carboxamido)ethyl)-4,6,7,12-tetrahydroindolo[2,3-a]quinolizine-6-carboxamide (ATIQCTPC) towards the active site of MMP-9, and showed that ATIQCTPC was able to effectively decrease the level of MMP-9 in the serum and the primary tumor of Lewis lung carcinoma (LLC) implanted C57BL/6 mice. As a MMP-9 inhibitor, ATIQCTPC inhibited the metastasis of LLC, and slowed the growth of the primary tumor of LLC implanted C57BL/ 6 in mice. The activities of ATIQCTPC to inhibit the ear edema and to decrease the serum levels of TNF-a and IL-8 of the mice treated with xylene were explored. The minimal effective dose of ATIQCTPC that can inhibit the primary tumour growth, prevent the metastasis of LLC and reduce the inflammatory response was $0.01 \mu \mathrm{mol} / \mathrm{kg}$. The minimal effective dose of ATIQCTPC inhibiting tumour growth and metastasis was 100-fold lower than that of (S)-3-acetyl- 4-0xo-4,6,7,12tetrahydroindolo[2,3-a]quinolizine-6-carboxylic acid (ATIQC, parent compound). The minimal effective dose of ATIQCTPC inhibiting inflammation was 110-fold lower than that of aspirin. These superiorities reflected the rationality of ATIQCTPC design. The safety of the therapy was explained by $1 \mu \mathrm{mol} / \mathrm{kg}$ of ATIQCTPC did not injure the kidney, the liver and the heart of the treated inflammation mice.

\section{INTRODUCTION}

The investigations of matrix metalloproteinase-9 (MMP-9) have attracted the interests of a series of fields. The medical investigations of MMP-9 advance the cancer therapy and the prevention of tumor metastasis. Of the progresses that push the medical investigation forward should be the inhibitors of MMP-9 in targeting therapy. The impact of MMP-9 to tumorigenesis and targeting therapy has been well known [1]. The activation of MMP-9 leads to the migration of breast cancer cells [2]. The relevant expression of MMP-9 in lung tissue induces lung cancer [3]. MMP-9 is considered a potential biomarker of osteosarcoma [4], and is intensely implicated in metastatic progression of colorectal cancer [5]. The inhibition of MMP-9 can effectively attenuate cancer metastasis [6], and at early stages 
of cancer the inhibition of MMP-9 is essentially efficacy [5]. Usually, the cause of the death of the cancer patients is the metastasis rather than the primary tumor. This emphasizes the importance of inhibiting MMP-9 [5-7]. To prevent the cancer patients from metastatic death, a series of MMP9 inhibitors such as bioactive polyphenols of green tea $[8$, 9], naturally occurred products [10-12], clinical drugs [1316], and the synthetic compounds [17-20] were reported. Since most of these inhibitors received in vitro evaluation only, the in vivo active inhibitors are urgently needed. In this context, the present paper analyzed the structural characteristics of the above in vitro inhibitors, integrated their pharmacophores [10, 18-21], and designed (6S)-3acetyl-4-oxo-N (2-(3,4,5,6-tetrahydroxytetrahydro-2H-pyran2-carboxamido)ethyl)-4,6,7,12-tetrahydroindolo[2,3-a] quinolizine-6-carboxamide (ATIQCTPC) as an inhibitor of MMP-9 (Figure 1). The docking assay showed that, of the libdock scores (95.08-118.02) of the 5 compounds in Figure 1 and (2R)-2-[2-[[(2R,3R,4R,5S,6R)-3acetamido-4,5-diacetyl-oxy-6-(acetyloxymethyl)oxan-2-yl] carbamothioylamino] ethyl-(4-phenyl-phenyl)sulfonylamino]3-methylbutanoic acid (the standard ligand), ATIQCTPC had the highest score (118.02, see Supplementary Table 2). Figure 1 also shows that the 6 interactions of hydrogen bonds between ATIQCTPC and the side chains of the amino acid residues in the active site of MMP-9 are the major interactions between the standard ligand and the side chains of the amino acid residues in the active site of MMP-9 [22].

\section{RESULTS}

\section{ATIQCTPC effectively inhibits the migration of A549 cells}

The anti-migration activity of ATIQCTPC was evaluated with the in vitro migration assay of A549 and LLC cells, and the results are shown in Figure 2A, 2C, 2E and 2G. As seen, ATIQCTPC concentration-dependently inhibit the migration of A549 and LLC cells. The migration number of A549 and LLC cells treated with $0.2 \mu \mathrm{M}$ ATIQCTPC is significantly lower than that of A549 and LLC cells treated with phosphatebuffered saline (PBS), and equals to that of A549 and LLC cells treated with $20 \mu \mathrm{M}$ ATIQC. This means that antimigration activity of ATIQCTPC is 100-fold of ATIQC.

The anti-invasion activity of ATIQCTPC was evaluated with the in vitro invasion assay of A549 and LLC cells, and the results are shown in Figure 2B, 2D, $2 \mathrm{~F}$ and $2 \mathrm{H}$. As seen, ATIQCTPC concentration-dependently inhibit the invasion of A549 and LLC cells. The invasion number of A549 and LLC cells treated with $0.2 \mu \mathrm{M}$ ATIQCTPC is significantly lower than that of A549 and LLC cells treated with PBS, and equals to that of A549 and LLC cells treat by $20 \mu \mathrm{M}$ ATIQC. This means that anti-invasion activity of ATIQCTPC is 100 -fold of ATIQC.

\section{ATIQCTPC effectively inhibits the metastasis of LLC toward lung in vivo}

The anti-metastasis activity of ATIQCTPC was evaluated on Lewis lung carcinoma (LLC) sarcoma implanted $\mathrm{C} 57 \mathrm{BL} / 6$ mice, and the results are shown in Figure 3. Figure $3 \mathrm{~A}$ is the representative lungs of LLC sarcoma bearing C57BL/6 mice orally treated with NS for 11 days, with 1 $\mu \mathrm{mol} / \mathrm{kg} /$ day of ATIQC for 11 days and with $0.01 \mu \mathrm{mol} / \mathrm{kg} /$ day of ATIQCTPC for 11 days. On the front and the back of the lungs the metastasis nodules are marked with red rings.

Figure $3 \mathrm{~B}$ shows the statistical results of the metastasis nodules on the lungs. The number of lung metastasis nodules of the mice orally treated with 0.01 $\mu \mathrm{mol} / \mathrm{kg} /$ day of ATIQCTPC for 11 days is significantly lower than that of lung metastasis nodules of the mice orally treated with NS for 11 days, and is equal to that of lung metastasis nodules of the mice orally treated with $1 \mu \mathrm{mol} / \mathrm{kg}$ of ATIQC for 11 days. The data evidence that ATIQCTPC effectively inhibits LLC sarcoma metastasis towards the lung, and its activity is 100-fold of ATIQC.

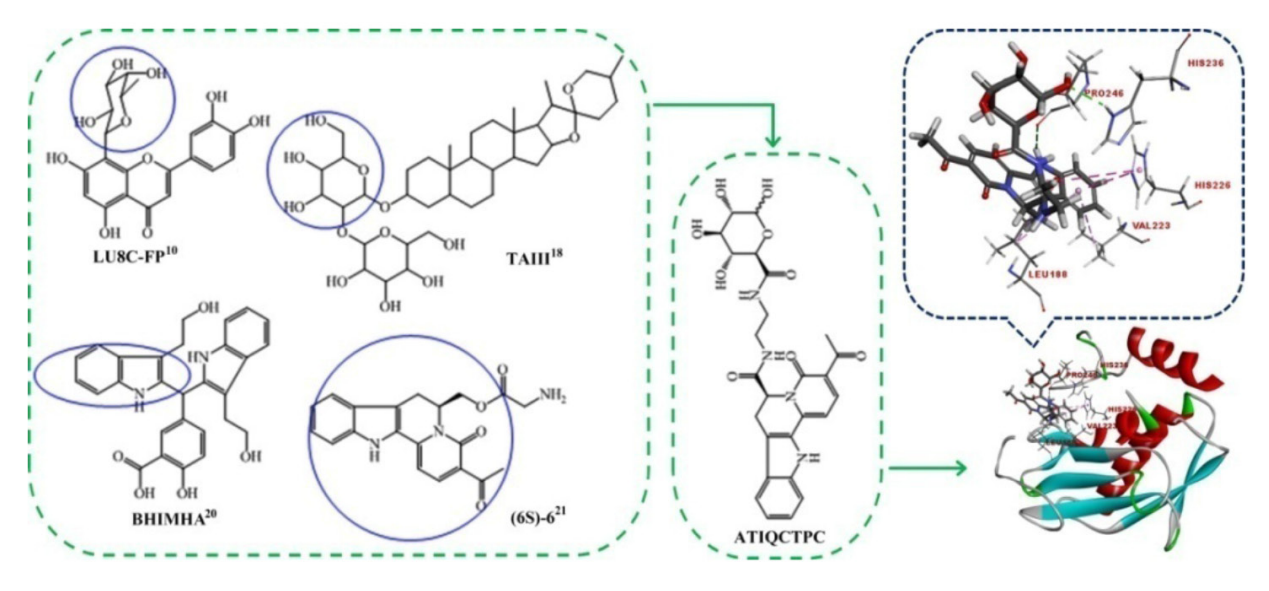

Figure 1: Pharmacophores based design and the active site of MMP-9 based docking of ATIQCTPC. 


\section{ATIQCTPC effectively decreases weight/ volume and MMP-9 of LLC sarcoma implanted C57BL/6 mice}

The anti-tumor activity of ATIQCTPC was evaluated on LLC sarcoma implanted C57BL/6 mice, and the primary tumor weights and volumes are shown in Figure 4A and 4B. The sarcoma weight/volume of LLC sarcoma implanted C57BL/6 mice orally treated with ATIQCTPC $(0.01 \mu \mathrm{mol} / \mathrm{kg} / \mathrm{day})$ for 11 days is significantly lower than that of LLC sarcoma implanted C57BL/6 mice orally treated with NS for 11 days, and is equal to that of LLC sarcoma implanted C57BL/6 mice orally treated with ATIQC ( $1 \mu \mathrm{mol} / \mathrm{kg} /$ day) for 11 days. The comparison suggests that ATIQCTPC effectively slows LLC sarcoma growth, and its activity is 100 folds of ATIQC. Besides,
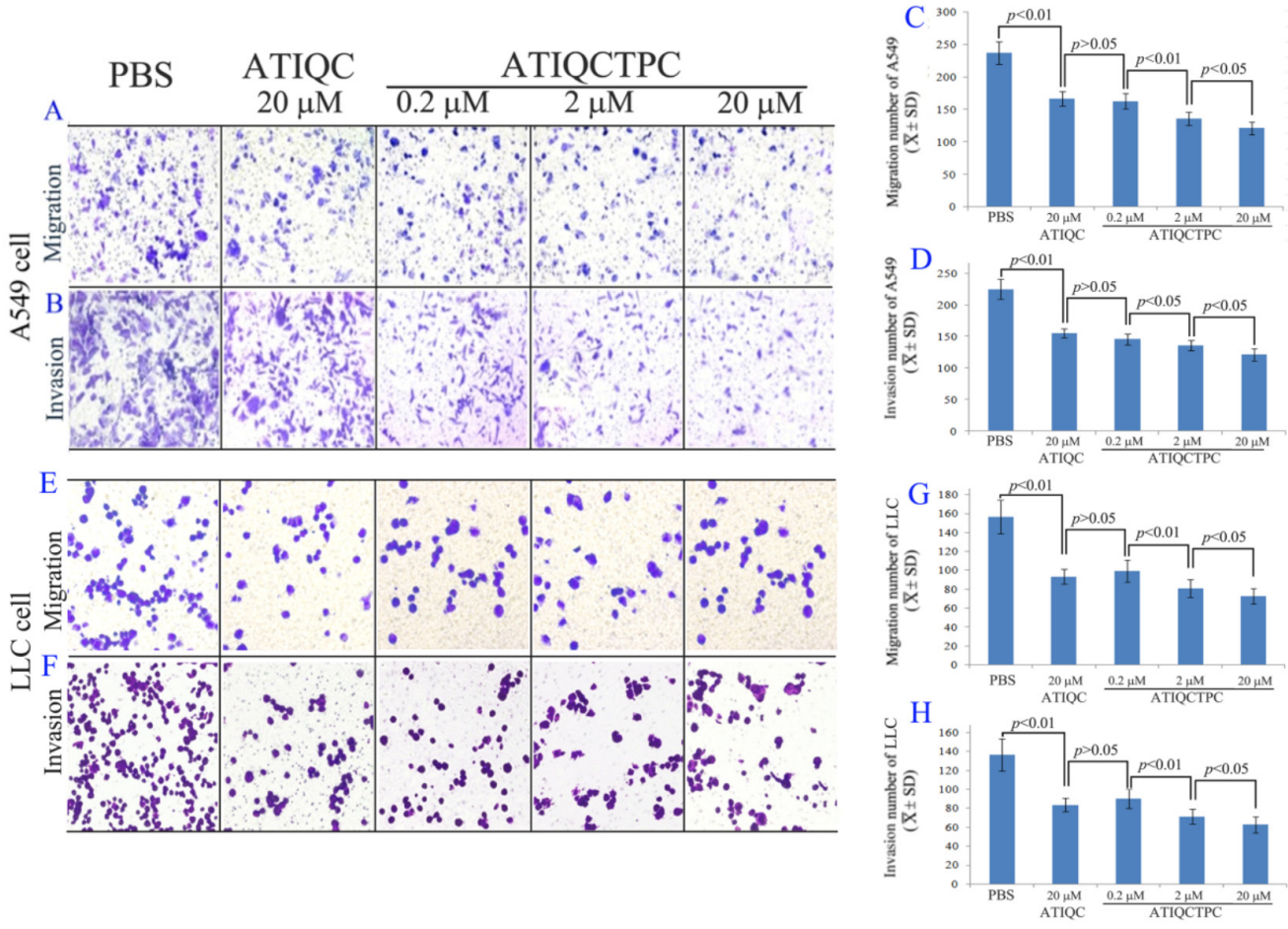

Figure 2: Effect of $0.2 \mu \mathrm{M}, 2 \mu \mathrm{M}$ and $20 \mu \mathrm{M}$ of ATIQCTPC on the migration of A549 cells (A and C), the invasion of A549 cells (B and $\mathbf{D})$, the migration of LLC cells $(\mathbf{E}$ and $\mathbf{G})$, the invasion of LLC cells $(\mathbf{F}$ and $\mathbf{H}), \mathrm{n}=12$.
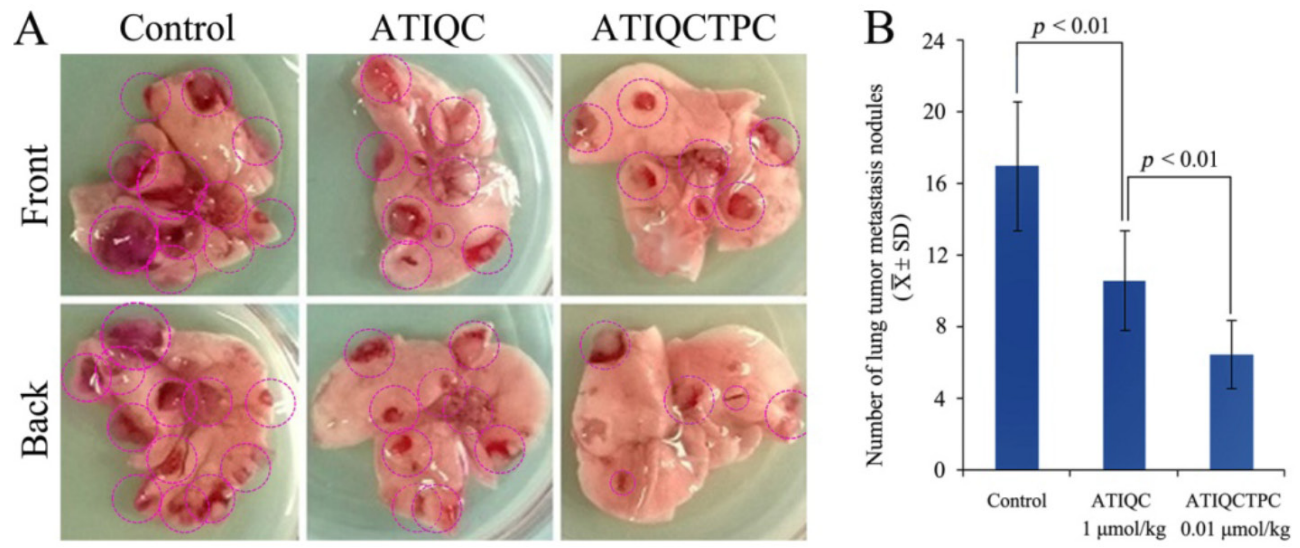

Figure 3: Effect of ATIQCTPC on the number of lung metastasis nodules of LLC sarcoma bearing C57BL/6 mice. (A) The representative lung of LLC sarcoma bearing C57BL/6 mice orally treated with NS for 11 days (left), the representative lung of LLC sarcoma bearing C57BL/6 mice orally treated with $1 \mu \mathrm{mol} / \mathrm{kg} / \mathrm{day}$ of ATIQC for 11 days (middle), and the representative lung of LLC sarcoma bearing C57BL/6 mice orally treated with $0.01 \mu \mathrm{mol} / \mathrm{kg} / \mathrm{day}$ of ATIQCTPC for $11 \mathrm{days}$ (right). (B) The number of lung metastasis nodules of LLC sarcoma bearing C57BL/6 mice orally treated with NS(control), ATIQC and ATIQCTPC, $\mathrm{n}=10$. 
the efficacy of ATIQCTPC in lowering LLC sarcoma weight is the same as it in limiting LLC sarcoma volume.

Figure 4C shows that the serum MMP-9 level of LLC sarcoma implanted C57BL/6 mice orally treated with ATIQCTPC $(0.01 \mu \mathrm{mol} / \mathrm{kg} /$ day $)$ for 11 days is significantly lower than that of LLC sarcoma implanted C57BL/6 mice orally treated with NS for 11 days. While Figure 4D shows that the MMP-9 level in the primary tumor of LLC sarcoma implanted C57BL/6 mice orally treated with ATIQCTPC $(0.01 \mu \mathrm{mol} / \mathrm{kg} /$ day $)$ for 11 days is significantly lower than MMP-9 level in the primary tumor of LLC sarcoma implanted C57BL/6 mice orally treated with NS for 11 days. These data suggest that the in vivo efficacy of ATIQCTPC $(0.01 \mu \mathrm{mol} / \mathrm{kg} /$ day for 11 days) effectively inhibiting the metastasis of LLC toward lung could be the result of it decreasing MMP-
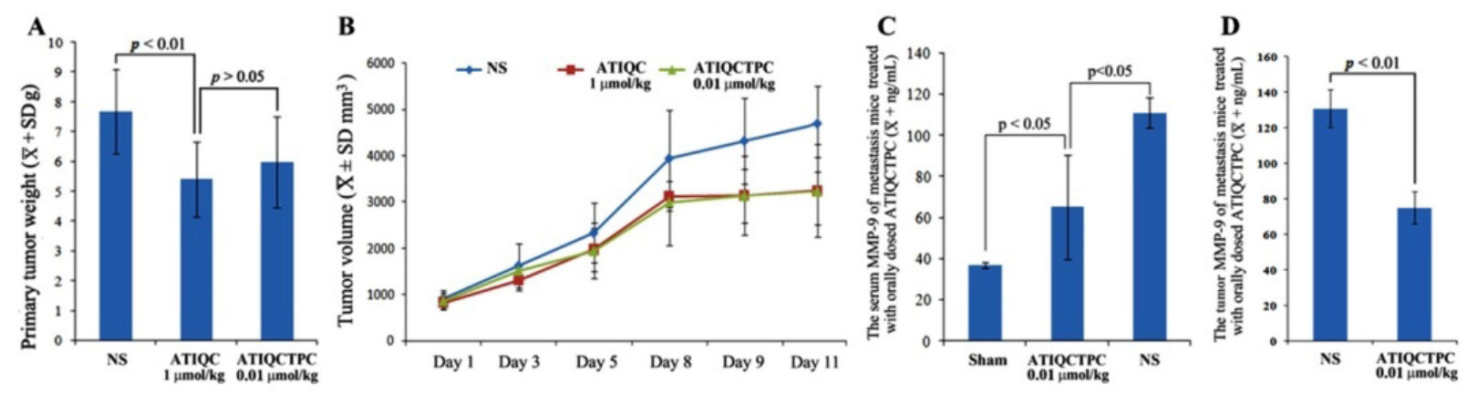

Figure 4: Effects of ATIQCTPC on the primary tumor weight (A) and volume (B), the level of MMP-9 in the serum (C) and the level of MMP-9 in the primary tumor (D) of LLC sarcoma implanted C57BL/6 mice, $\mathrm{n}=10$.
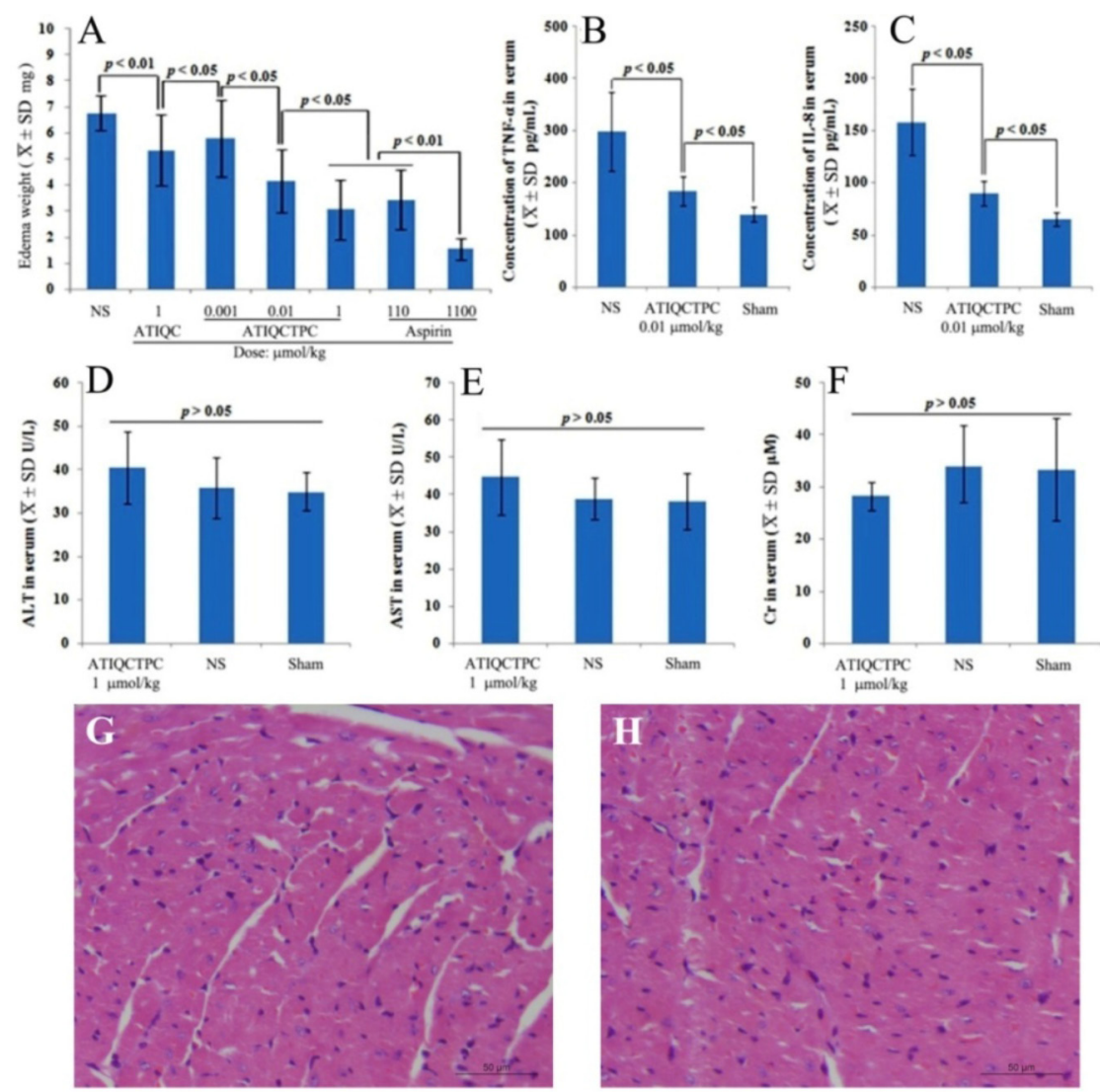

Figure 5: Effects of ATIQCTPC on xylene-induced ear edema. (A) Dose (0.001, 0.01 and $1 \mu \mathrm{mol} / \mathrm{kg})$ dependent inhibition of ATIQCTPC to xylene-induced ear edema. (B and C) Effect of $0.01 \mu \mathrm{mol} / \mathrm{kg}$ ATIQCTPC on the serum TNF- $\alpha$ and IL-8 of inflammation mice; Effect of $1 \mu \mathrm{mol} / \mathrm{kg}$ ATIQCTPC on the serum AST (D), the serum ALT (E) and the serum Cr (F) of the inflammatory mice. (G) The heart section with H\&E stain of the inflammatory mice treated by NS. (H) The heart section with H\&E stain of the inflammatory mice treated by $1 \mu \mathrm{mol} / \mathrm{kg}$ ATIQCTPC; $\mathrm{n}=12$. 
9 level in the serum and the primary tumor of LLC sarcoma implanted C57BL/6 mice.

\section{ATIQCTPC effectively decreases ear edema of the mice treated with xylene}

The relationship between MMP-9 expression and inflammatory response was well established [23-25]. This relationship encouraged the present paper to evaluate the anti-inflammation activity of ATIQCTPC on xyleneinduced ear edema mouse model, and the ear edema is shown in Figure 5A. ATIQCTPC inhibits ear edema of the mice in a dose $(0.001,0.01$ and $1 \mu \mathrm{mol} / \mathrm{kg})$ dependent manner. The ear edema of the mice orally treated with $0.01 \mu \mathrm{mol} / \mathrm{kg}$ ATIQCTPC is significantly lower than those of the mice orally treated with NS and $1 \mu \mathrm{mol} / \mathrm{kg}$ ATIQC. This comparison suggests that the minimal effective dose of ATIQCTPC in inhibiting inflammation is $0.01 \mu \mathrm{mol} / \mathrm{kg}$ and its activity is 100-fold higher than that of ATIQC. Besides, the ear edema of the mice orally treated with $1 \mu \mathrm{mol} / \mathrm{kg}$ ATIQCTPC is equal to that of the mice orally treated with $110 \mu \mathrm{mol} / \mathrm{kg}$ aspirin. This comparison suggests that the anti-inflammation activity of ATIQCTPC is 110 folds of aspirin.

\section{ATIQCTPC effectively decreases serum TNF- $\alpha$ and IL-8 of inflammation mice}

The relationships between MMP-9, tumor necrosis factor- $\alpha$ (TNF- $\alpha$ ), interleukin- 8 (IL-8) and inflammatory were widely reported [26-29]. These encouraged this paper to evaluate the serum TNF- $\alpha$ and IL- 8 of ATIQCTPC treated inflammatory mice, and the results are shown in Figure 5B and 5C. At a dose of $0.01 \mu \mathrm{mol} / \mathrm{kg}$ ATIQCTPC do effectively decrease the serum levels of TNF- $\alpha$ and IL- 8 of the inflammatory mice. These findings suggest that $0.01 \mu \mathrm{mol} / \mathrm{kg}$ ATIQCTPC is capable of simultaneous decrease the serum MMP-9, TNF- $\alpha$ and IL-8 in vivo.

\section{ATIQCTPC does not injure the kidney, the liver and the heart}

To estimate the therapeutic toxicity the serum levels of ALT, AST and Cr of the inflammatory mice orally treated with $1 \mu \mathrm{mol} / \mathrm{kg}$ ATIQCTPC were measured, and the data are shown in Figure 5D-5F. As seen, after the treatment the serum levels of ALT, AST and $\mathrm{Cr}$ of the mice are not significantly changed. This means that $1 \mu \mathrm{mol} / \mathrm{kg}$ ATIQCTPC does not injure the kidney and the liver. Besides the H\&E stain of the heart sections of the inflammatory mice is also performed. Figure $5 \mathrm{G}$ and $5 \mathrm{H}$ show that the heart sections of the mice treated with NS and ATIQCTPC have the similar myocardium histology. This ensures that ATIQCTPC induces no heart damage. Due to the dose of ATIQCTPC for evaluating serum ALT, AST and $\mathrm{Cr}$ and staining heart sections is 110 -fold higher than that of its minimal effective dose, the safe window of ATIQCTPC is high enough.

\section{ATIQCTPC effectively scavenges NO• free radicals}

The effect of NO free radical and MMP-9 on the inflammation and cancer, as well as the interaction between NO free radical and MMP-9 have been well

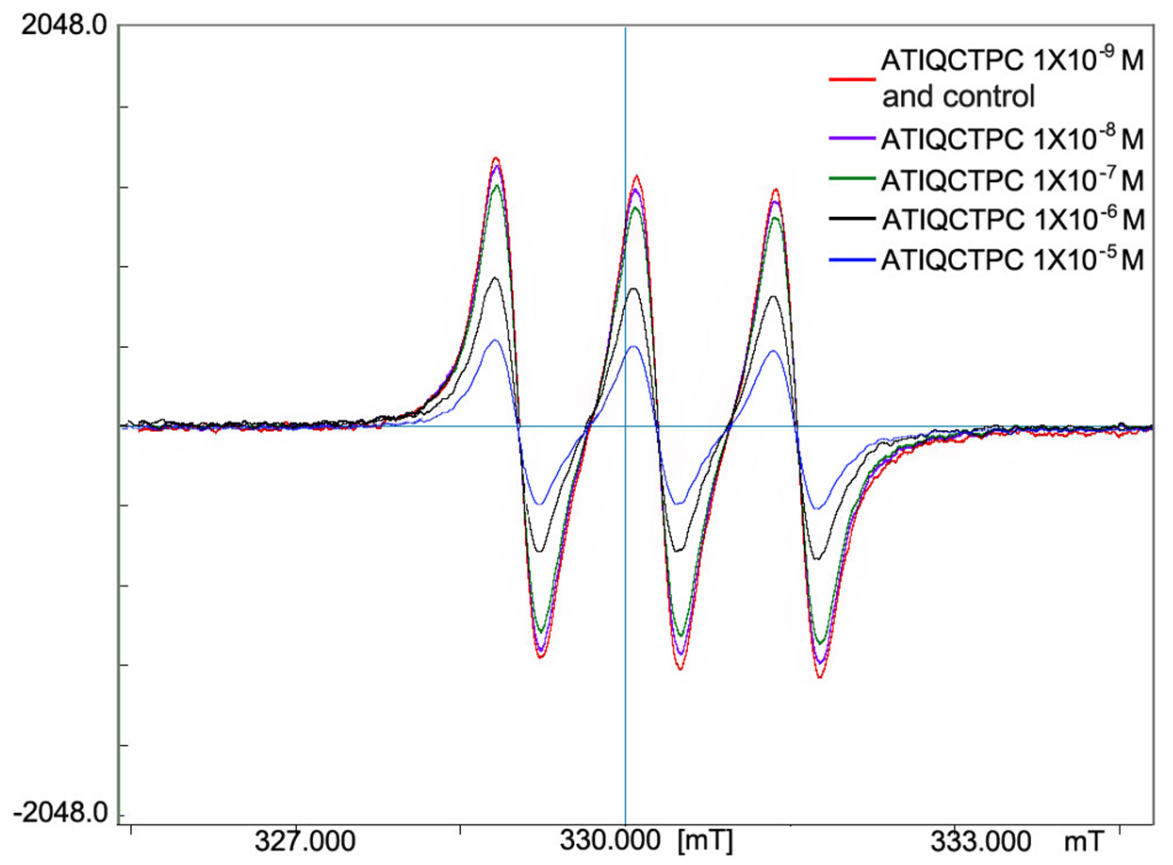

Figure 6: ATIQCTPC concentration-dependently scavenging NO• free radicals, $\mathbf{n}=6$. 
known [30]. To explore the contribution of ATIQCTPC scavenging $\mathrm{NO} \bullet$ free radical in decreasing serum level of MMP-9, the in vitro NO• free radical scavenging assay was performed. Figure 6 indicates that the signal of $\mathrm{NO}$ • free radicals is gradually decreased by ATIQCTPC in a concentration (final concentration: $10^{-5} \mathrm{M}, 10^{-6} \mathrm{M}, 10^{-7} \mathrm{M}$, $10^{-8} \mathrm{M}$ and $10^{-9} \mathrm{M}$ ) dependent manner.

\section{DISCUSSION}

The docking of ATIQCTPC towards the active site of MMP-9 could meet the requirements of a ligand for MMP9 inhibition [22], and suggests that ATIQCTPC can target MMP-9, thereby lead to the decrease of serum MMP-9 and primary tumor MMP-9 of LLC sarcoma implanted C57BL/6 mice orally treated with ATIQCTPC $(0.01 \mu \mathrm{mol} / \mathrm{kg} /$ day $)$ for 11 days. This targeting action benefits ATIQCTPC to inhibit the migration and the invasion of A549 and LLC cells in vitro. Furthermore this targeting action benefits ATIQCTPC to decrease the number of lung metastasis nodules of LLC sarcoma implanted C57BL/6 mice in particular. Surprisingly, the 11-day treatment of oral ATIQCTPC $(0.01 \mu \mathrm{mol} / \mathrm{kg} /$ day $)$ could effectively decrease the weight and volume of the primary tumor of LLC sarcoma implanted C57BL/6 mice. These findings indicate that ATIQCTPC possesses dual inhibitions of tumor growth and tumor metastasis.

The effect of inflammation on tumor progression and metastasis has been widely demonstrated [31-35]. To understand the anti-tumor and anti-metastasis dual actions of ATIQCTPC the anti-inflammation evaluations were performed. On xylene-induced ear edema mouse model 0.01 $\mu \mathrm{mol} / \mathrm{kg}$ ATIQCTPC effectively inhibits ear edema of the mice. This observation explains the reason of $0.01 \mu \mathrm{mol} / \mathrm{kg}$ ATIQCTPC possessing dual inhibitions of tumor growth and tumor metastasis. Besides, $0.01 \mu \mathrm{mol} / \mathrm{kg}$ ATIQCTPC also effectively decreases the serum levels of TNF- $\alpha$ and IL- 8 of the inflammatory mice. These observations emphasize the relationships of MMP-9, TNF- $\alpha$, IL- 8 and inflammatory [26-29]. In the pathology of the inflammation and the cancer NO - free radicals and MMP-9 are usually higher [30]. The concentration dependent scavenging of $\mathrm{NO} \bullet$ free radicals gives another understanding of ATIQCTPC having dual inhibitions of tumor growth and tumor metastasis. The concentration dependent scavenging of $\mathrm{NO} \bullet$ free radicals also implys that via decreasing the level of $\mathrm{NO} \bullet$ free radicals ATIQCTPC contributes to the inhibition of MMP-9.

In respect of the in vivo benefit of ATIQCTPC inhibiting MMP-9, the activity profiles are the solid evidences. On LLC sarcoma implanted C57BL/6 mouse model the activities of ATIQCTPC in the inhibition of the lung metastasis of LLC and in the slowing of the primary tumor growth are 100-fold higher than those ofATIQC, and the parent compound of ATIQCTPC. On xyleneinduced ear edema mouse model the anti-inflammation activity of ATIQCTPC is 100-fold higher than those of ATIQC and aspirin.
Even though the minimal effective dose of ATIQCTPC to inhibit the lung metastasis of LLC, to slow the primary tumor growth, and to block xylene induced ear edema is low to $0.01 \mu \mathrm{mol} / \mathrm{kg}$, at the dose of $1 \mu \mathrm{mol} /$ $\mathrm{kg}$ ATIQCTPC does not injure the kidney, the liver and the heart of the inflammation mice. Therefore ATIQCTPC therapy is safe enough.

\section{MATERIALS AND METHODS}

\section{General}

C57BL/6 mice and ICR mice were purchased from the Animal Center of Capital Medical University. Work performed was based on a protocol reviewed and approved by the ethics committee of Capital Medical University. The committee assures that the welfare of the mice was maintained in accordance with the requirements of the Animal Welfare Act. Statistical analyses of all the biological data were carried out by use of analysis of variance. $P$-values $<0.05$ were considered statistically significant. The amino acids (L-configuration), and sodium citrate (analytically pure) were available commercially (Sigma-Aldrich Corp, St Louis MO, USA), acetonitrile spectroscopically pure was available commercially (Thermo Fisher Scientific, Waltham, MA, USA). ATIQCTPC was prepared by following the route depicted in Supplementary Figure 1 of Supplementary Materials. The procedures and the physical/chemical data of the intermediates and ATIQCTPC were also provided in Supplementary Materials. According to Supplementary Materials the HPLC purity of ATIQCTPC is more than $99 \%$. And the IC50 values for 6 cell lines were listed in Supplementary Table 1.

\section{Cell migration assay}

Transwell chamber with cell permeable membrane was used, and A549 and LLC cell migration assays were performed by following a standard method [36]. In brief, A549 cells $\left(5 \times 10^{4}\right.$ cells/chamber $)$ and serum-free medium in the upper chamber were treated with ATIQC $(20 \mu \mathrm{M})$ or ATIQCTPC $(20 \mu \mathrm{M})$. The medium with $10 \% \mathrm{FBS}$, the chemotactic factor, was added into the down chamber (600 $\mu \mathrm{L} /$ chamber), the transwell chamber was incubated at $37^{\circ} \mathrm{C}$ for $6 \mathrm{~h}$, and $\mathrm{A} 549$ cells that did not penetrate the membrane and at the bottom of the upper chamber were removed with cotton swabs. A549 cells were fixed with PBS containing 4\% formaldehyde for $30 \mathrm{~min}$ and stained with $0.1 \%$ crystal violet for $15 \mathrm{~min}$. A549 cells that penetrated through the membrane into the down chamber were counted under a light microscope at $\times 200$ to take the count of the cells from 9 visual fields.

\section{Cell invasion assay}

Transwell chamber with cell permeable membrane was used, and A549 and LLC cell migration assays were 
performed by following a standard method [31]. Membrane at the bottom of each chamber was coated with $50 \mu \mathrm{L}$ matrigel and air-dried overnight. The chamber was blocked with bovine serum albumin (BSA, $2 \%, 50 \mu \mathrm{L} /$ chamber), incubated at $37{ }^{\circ} \mathrm{C}$ for $2 \mathrm{~h}$, and rinsed with PBS. A549 cells $\left(2 \times 10^{4}\right.$ cells/chamber) and serum-free medium in the upper chamber were treated with ATIQC $(20 \mu \mathrm{M})$ or ATIQCTPC $(20 \mu \mathrm{M})$. Into the down chamber, $600 \mu \mathrm{L}$ of FBS (10\%) was added. A549 cells were cultured at $37^{\circ} \mathrm{C}$ for $24 \mathrm{~h}$ and A549 cells that did not penetrate the membrane were removed with cotton swabs. The cells penetrated through the membrane were fixed with $4 \%$ formaldehyde for $30 \mathrm{~min}$ and stained with $0.1 \%$ crystal violet for $10 \mathrm{~min}$. A549 cells that penetrated through the matrigel were counted under a light microscope at $\times 200$ to take the count of the cells from 9 visual fields.

\section{In vivo LLC sarcoma growth and metastasis inhibition assay}

Male C57BL/6 mice were maintained at $21^{\circ} \mathrm{C}$ with a natural day/night cycle in a conventional animal colony. C57BL/6 mice were 10 -week old at the beginning of the assay. LLC cells were subcutaneously injected to form solid tumors. To initiate subcutaneous tumors, LLC cells obtained in homogenates of sarcoma form tumor-bearing mice were serially transplanted once per 2 weeks. Subcutaneous tumors were implanted under the skin at the right armpit by injecting $0.2 \mathrm{~mL} \mathrm{NS}$ containing $1 \times 10^{7}$ viable tumor cells. Ten days after implantation mice were randomly divided into treatment groups (10 per group) and treated with orally dosed ATIQCTPC $(0.01 \mu \mathrm{mol} / \mathrm{kg})$ or ATIQC $(1 \mu \mathrm{mol} / \mathrm{kg}$ ) or NS (vehicle) every day for 11 days. C57BL/6 mice were weighed daily and the tumor volume was measured every day. Twenty-four hours after the last administration, the tumor volume was measured and calculated with Length $\times$ Width $\times$ Width $/ 2^{3}$, mice were weighed, sacrificed by ether anesthesia, and dissected to immediately obtain and weigh the tumors, and the lungs were also removed and visually examined for the occurrence of tumor metastasis and the numbers of metastatic tumor nodules.

\section{MMP-9 in the primary tumor and the serum of LLC sarcoma implanted C57BL/6 mice}

The primary tumor and the blood of C57BL/6 mice receiving in vivo sarcoma growth and metastasis inhibition assay were homogenized and collected, respectively. Then they were centrifuged at $500 \mathrm{~g}$ for $10 \mathrm{~min}$ to get the primary tumor and serum samples. The MMP-9 in the primary tumor and the serum of the mice treated with ATIQCTPC $(0.01 \mu \mathrm{mol} / \mathrm{kg})$ or ATIQC $(1 \mu \mathrm{mol} / \mathrm{kg})$ or NS (vehicle) was measured according to the guidance of the kits (Mouse Total MMP-9ELISA kit, R\&D Systems, Inc., USA).

\section{In vivo anti-inflammatory assay}

Male ICR mice weighing $25 \pm 2 \mathrm{~g}$ were housed in a $12 / 12$ light/dark cycle at a room temperature of $21 \pm 2^{\circ} \mathrm{C}$ for 2 days before use. Food and tap water were supplied ad libitum. The mice were randomly divided into 7 groups of 12 mice, and received ATIQCTPC $(0.001,0.01$ and $1 \mu \mathrm{mol} / \mathrm{kg})$ or ATIQC $(1 \mu \mathrm{mol} / \mathrm{kg})$ or aspirin (110 and $1 \mu \mathrm{mol} / \mathrm{kg}$ ) or NS. Thirty minutes later, $0.03 \mathrm{~mL}$ of xylene was applied to both the anterior and posterior surfaces of the right ear. The left ear was a control. Two hours after xylene application, the mice were weighed, sacrificed by ether anesthesia, and both ears were removed. With a rubber plug punch of $7 \mathrm{~mm}$ aperture the circular sections were taken from the ears for weigh. The ear edema induced by xylene irritant was obtained through subtracting the weight of xylene untreated left ear section from that of xylene treated right ear section.

\section{Measuring the TNF-a and IL-8 in the serum of ear edema mice}

Into an Eppendorf tube containing $50 \mu \mathrm{L}$ aqueous sodium citrate $(3.8 \%), 450 \mu \mathrm{L}$ of blood were collected from the inflammatory mice orally receiving NS or $0.01 \mu \mathrm{mol} / \mathrm{kg}$ of ATIQCTPC, and centrifuged at $200 \mathrm{~g}$ for $20 \mathrm{~min}$ to get the serum. Then, TNF- $\alpha$ and IL- 8 in serum were measured according to the guidance of the kits (Mouse TNF- $\alpha$ ELISA kit, Mouse IL-8 ELISA kit, Xitang Biotechnology Co., Shanghai, People's Republic of China).

\section{Liver and kidney injury assay for inflammatory mice}

Into an Eppendorf tube containing $50 \mu \mathrm{L}$ aqueous sodium citrate $(3.8 \%), 450 \mu \mathrm{L}$ of blood was collected from the inflammatory mice orally receiving NS or $1 \mu \mathrm{mol} / \mathrm{kg}$ ATIQCTPC and centrifuged at $500 \mathrm{~g}$ for $10 \mathrm{~min}$ to get serum samples. Then, alanine transaminase (ALT), aspartate transaminase (AST) and creatinine $(\mathrm{Cr})$ in serum were measured according to guidance of the kits (AST/ GOT testing kit, ALT/GPT testing kit, $\mathrm{Cr}$ testing kit; JCBIO Co., Nanjing, People's Republic of China).

\section{NO• free radical scavenging assay}

$\mathrm{NO} \cdot$ free radicals were produced by the reaction of $5 \mu \mathrm{L}$ solution of $7.325 \mathrm{mg} \mathrm{N}$-methyl-D-glucamine dithiocarbamate (MGD, Sigma) in $1 \mathrm{~mL}$ ultrapure water $(25 \mathrm{mM}), 5 \mu \mathrm{L}$ solution of $3.475 \mathrm{~g} \mathrm{FeSO}_{4} \cdot 7 \mathrm{H}_{2} \mathrm{O}$ (Sinopharm Chemical Reagent Beijing Co., Ltd) in 1 $\mathrm{mL}$ ultrapure water $(12.5 \mathrm{mM}), 5 \mu \mathrm{L}$ solution of 0.25 $\mathrm{mg}$ of S-nitroso-N-acetyl-DL-penicillamine (SNAP, Sigma) in $1 \mathrm{~mL}$ ultrapure water $(1.1 \mu \mathrm{M})$, and the signal was recorded on JEOL JES300 ESR as a control of NO• signal (BHNO). The effect of ATIQCTPC on 
$\mathrm{NO} \bullet$ free radicals was defined by comparing the signal of $\mathrm{NO} \bullet$ free radicals formed from the reaction of $5 \mu \mathrm{L}$ solution of $7.325 \mathrm{mg}$ of MGD in $1 \mathrm{~mL}$ ultrapure water ( $25 \mathrm{mM}$ ), $5 \mu \mathrm{L}$ solution of $3.475 \mathrm{~g} \mathrm{FeSO}_{4} \cdot 7 \mathrm{H}_{2} \mathrm{O}$ in 1 $\mathrm{mL}$ ultrapure water $(12.5 \mathrm{mM}), 5 \mu \mathrm{L}$ solution of 0.25 mg SNAP in $1 \mathrm{~mL}$ ultrapure water $(1.1 \mu \mathrm{M})$ and $5 \mu \mathrm{L}$ solution of ATIQCTPC in $1 \mathrm{~mL}$ ultrapure water (final concentration: $10^{-5}, 10^{-4}, 10^{-3} \mathrm{M}$ ) with the control of $\mathrm{NO} \bullet$ signal.

\section{ACKNOWLEDGMENTS}

The authors thank the NSFC $(81373265,81673303$ and 81373264), the Beijing Natural Science Foundation (7162025 and 7172028), PHR (KZ201610025029 and KM201710025009), Special Project (2017ZX09201008) of China, and the 863 Program (2015AA020902) for financial supports.

\section{CONFLICTS OF INTEREST}

The authors declare no conflicts of interest.

\section{REFERENCES}

1. Candido S, Abrams SL, Steelman LS, Lertpiriyapong K, Fitzgerald TL, Martelli AM, Cocco L, Montalto G, Cervellog M, Polesel J, Libra M, McCubrey JA. Roles of NGAL and MMP-9 in the tumor microenvironment and sensitivity to targeted therapy. Biochim Biophys Acta. 2016; 1863:438-448.

2. Gil M, Kim YK, Kim KE, Kim W, Park CS, Lee KJ. Cellular prion protein regulates invasion and migration of breast cancer cells through MMP-9 activity. Biochem Bioph Res Co. 2016; 470:213-219.

3. Zhang DH, Zhang LY, Liu DJ, Yang F, Zhao JZ. Expression and significance of MMP-9 and MDM2 in the oncogenesis of lung cancer in rats. Asian Pac J Trop Med. 2014; 7:585-588.

4. Wang J, Shi Q, Yuan TX, Song QL, Zhang Y, Wei Q, Zhou L, Luo J, Zuo G, Tang M, He TC, Weng Y. Matrix metalloproteinase 9 (MMP-9) in osteosarcoma: review and meta-analysis. Clinica Chimica Acta. 2014; 433:225-231.

5. Herszényi L, Lakatos HG, Varga MZ, Tulassay Z. The behavior ofmatrix metalloproteinases and their inhibitors in colorectal cancer. Int J Mol Sci. 2012; 13:13240-13263.

6. Coussens LM, Fingleton B, Matrisian LM. Matrix metalloproteinase inhibitors and cancer: trials and tribulations. Science. 2002; 295: 2387-2392.

7. Ndinguri MW, Bhowmick M, Tokmina-Roszyk D, Robichaud TK, Fields GB. Peptide-based selective inhibitors of matrix metalloproteinase mediated activities. Molecules. 2012; 30:14230-14248.
8. Turkeli A, Yilmaz O, Taneli F, Horasan GD, Kanik ET, Kizilkaya M, Gozukara C, Yuksel H. IL-5, IL-8 and MMP -9 levels in exhaled breath condensate of atopic and nonatopic asthmatic children. Resp Med. 2015; 109:680-688.

9. Zhang C, Gong W, Liu H, Guo Z, Ge S. Inhibition of matrix metalloproteinase-9 with low-dose doxycycline reduces acute lung injury induced by cardiopulmonary bypass. Int J Clin Exp Med. 2014; 7:4975-4982.

10. Park SH, Kim JH, Lee DH, Kang JW, Song HH, Oh SR, Yoon DY. Luteolin 8-C-b-fucopyranoside inhibits invasion and suppresses TPA-induced MMP-9 and IL-8 via ERK/ AP-1 and ERK/NF-kB signaling in MCF-7 breast cancer cells. Biochimie. 2013; 95:2082-2090.

11. Nam H, Kim MM. Eugenol with antioxidant activity inhibits MMP-9 related to metastasis in human fibrosarcoma cells. Food Chem Toxicol. 2013; 55:106-112.

12. Lee WT, Lee TH, Cheng CH, Chen KC, Chen YC, Lin CW. Antroquinonol from Antrodia Camphorata suppresses breast tumor migration/invasion through inhibiting ERK-AP-1and AKT-NF-кBdependentMMP-9 and epithelialmesenchymal transition expressions. Food Chem Toxicol. 2015; 78:33-41.

13. Wang YY, Li H, Wang XH, Yuan M, Li GP. Probucol inhibits MMP-9 expression through regulating miR-497 in HUVECs and apoE knockout mice. Thromb Res. 2016; 140:51-58.

14. Chen YJ, Chang LS. Simvastatin induces NFkB/p65 downregulation and JNK1/c-Jun/ATF-2 activation, leading to matrix metalloproteinase-9 (MMP-9) but notMMP-2 downregulation in human leukemia cells. Biochem Pharmacol. 2014; 92:530-543.

15. Lee JY, Chung TW, Choi HJ, Lee CH, Eun JS, Han YT, Choi JY, Kim SY, Han CW, Jeong HS, Ha KT. A novel cantharidin analog N-Benzylcantharidinamide reduces theexpression of MMP-9 and invasive potentials of Hep3B via inhibitingcytosolic translocation of HuR. Biochem Bioph Res Co. 2014; 447:371-377.

16. Farina AR, Cappabianca L, Ianni ND, Ruggeri $P$, Ragone M, Merolle S, Gulino A, Mackay AR. Alendronate promotes plasmin-mediated MMP-9 inactivation by exposingcryptic plasmin degradation sites within the MMP-9 catalytic domain. FEBS Lett. 2012; 586:2366-2374.

17. Yan XQ, Wang ZC, Li Z, Wang PF, Qiu HY, Chen LW, Lu XY, Lv PC, Zhu HL. Sulfonamide derivatives containing dihydropyrazole moieties selectively and potently inhibit MMP-2/MMP-9: design, synthesis, inhibitory activity and 3D-QSAR analysis. Bioorg Med Chem Lett. 2015; 25:4664-4671.

18. Jung O, Lee J, Lee YJ, Yun JM, Son YJ, Cho JY,Ryou C, Lee SY. Timosaponin AIII inhibits migration and invasion of A549 human non-small-cell lung cancer cells via attenuations of MMP-2 and MMP-9 by inhibitions of ERK1/2, Src/FAK and b-catenin signaling pathways. Bioorg Med Chem Lett. 2016; 26:3963-3967. 
19. Lobo G, Monasterios M, Rodrigues J, Gamboa N, Capparelli MV, Martínez-Cuevas J, Lein M, Jung K, Abramjuk C, Charris J. Synthesis, crystal structure and effect of indeno[1,2-b]indole derivatives on prostate cancer in vitro. Potential effect against MMP-9. Eur J Med Chem. 2015; 96:281-295.

20. Gan T, Wang Y, Zhao M, Wu J, Yang J, Peng S. 5-(Bis(3(2-hydroxyethyl)-1H-indol-2-yl) methyl)-2-hydroxybenzoic acid (BHIMHA): Showing a strategy of designing drug to block lung metastasis of tumors. Drug Des Dev Ther. 2016; 10:711-721.

21. Zhao M, Wang C, Guo M, Peng S, Winterfeldt E. Synthesis of 6-amino acid substituted 4,6,7,12-tetrahydro-4-oxoindolo [2,3-a]quinolizines. J Parkt Chem. 1999; 341:692-694.

22. Nuti E, Cuffaro D, D'Andrea F, Rosalia L, Tepshi L, Fabbi M, Carbotti G, Ferrini S, Santamaria S, Camodeca C, Ciccone L, Orlandini E, Nencetti S, Stura EA, Dive V, Rossello A. Sugar-based arylsulfonamide carboxylates as selective and water-soluble matrix metalloproteinase-12 inhibitors. Chemmedchem. 2016; 11:1626-1637.

23. Hong JM, Kwon OK, Shin IS, Song HH, Shin NR, Jeon CM, Oh SR, Han SB, Ahn KS. Anti-inflammatory activities of Physalis alkekengi var. franchetiiextract through the inhibition of MMP-9 and AP-1 activation. Immunobiology. 2015; 220:1-9.

24. Bruschi F, D’Amato C, Piaggi S, Bianchi C, Castagna B, Paolicchi A, Pinto B. Matrix metalloproteinase (MMP)9: a realiable marker forinflammation in early human trichinellosis. Vet Parasitol. 2016; 231:132-136.

25. Halade GV, Jin YF, Lindsey ML. Matrix metalloproteinase (MMP)-9: a proximal biomarker for cardiac remodeling and a distal biomarker for inflammation. Pharmacol Therapeut. 2013; 139:32-40.

26. Turkeli A, Yilmaz O, Taneli F, Horasan GD, Kanik ET, Kizilkaya M, Gozukara C, Yuksel H. IL-5, IL-8 and MMP -9 levels in exhaled breath condensate of atopic and nonatopicasthmatic children. Resp Med. 2015; 109:680-688.

27. Sadarani BN, Majumdar AS. Resveratrol potentiates the effect of dexamethasone in rat model of acute lung inflammation. Int Immunopharmacol. 2015; 28: 773-779.
28. Tsai CL, Chen WC, Lee IT, Chi PL, Cheng SE, Yang CM. c-Src-dependent transactivation of PDGFR contributes to TNF- $\alpha$-induced MMP-9 expression and functional impairment in osteoblasts. Bone. 2014; 60:186-197.

29. Choudhurya R, Das P, De T, Chakraborti T. 115 kDa serine protease confers sustained protection to visceral leishmaniasis caused by Leishmania donovani via IFN- $\gamma$ induced down-regulation of TNF- $\alpha$ mediated MMP-9 activity. Immunobiology. 2013; 218:114-126.

30. O’Sullivan S, Medina C, Ledwidge M, Radomski MW, Gilmer JF. Nitric oxide-matrix metaloproteinase-9 interactions: biological and pharmacological significance: NOand MMP-9 interactions. Biochimi Biophys Acta. 2014; 1843: 603-617.

31. Rodvold JJ, Mahadevan NR, Zanetti M. Immune modulation by ER stress and inflammation in the tumor microenvironment. Cancer Lett. 2016; 380:227-236.

32. Shina TH, Brynczka C, Dayyani F, Rivera MN, Sweetser DA. TLE4 regulation of wnt-mediated inflammation underlies its role as atumor suppressor in myeloid leukemia. Leukemia Res. 2016; 48:46-56.

33. Dagistan Y, Dagistan E, Citisli V. Evaluation of simple blood counts as inflammation markers for brain tumor patients. Neurol Neurochir Pol. 2016; 50:231-235.

34. Salem M, Attia ZI, Galal SM. Acute inflammation induces immunomodulatory effects on myeloid cells associated with anti-tumor responses in a tumor mouse model. J Adv Res. 2016; 7:243-253.

35. Samadi AK, Bilsland A, Georgakilas AG, Amedei A, Amin A, Bishayee A, Azmi AS, Lokeshwar BL, Grue B, Panis C, Boosani CS, Poudyal D, Stafforini DM, et al. A multi-targeted approach to suppress tumor-promoting inflammation. Semin Cancer Biol. 2015; 35:S151-S184.

36. Wang F, Li S, Wang Y, Zhu H, Zhang X, Zhao M, Wu J, Peng S. Enantiomeric diketopiperazines: getting insight of the impact of the configuration to the conformation, nanoimage, u-PA inhibition and anti-metastatic activity. Med Chem Comm. 2015;6:956-962. 